\title{
Post-Holocaust Subjective Memories of the Eastern Carpathians Ethnic Diversity
}

\begin{abstract}
The article examines subjective memories of two writers, Stanisław Vincenz and Aharon Appelfeld, who both omit central historical aspects while describing their Holocaust experiences. The works of the Polish writer Stanisław Vincenz and an excerpt from a work by the Israeli writer Aharon Appelfeld are interpreted while considering the role of historiographic metafiction in modern literature. Though the experiences of both authors are fairly different, their silence may be treated as an act of conscious forgetting, or as a mindful choice of Holocaust recollection. It is suggested that this silence actually offers a valuable perspective for both literary and historical research. While Appelfeld's experience of the Holocaust was different from that of Vincenz, the silence of the authors carries profound meanings. Reading Vincenz and Appelfeld as historiographic metafiction is to read their silence.
\end{abstract}

Keywords: Stanisław Vincenz, Aharon Appelfeld, memory, Holocaust, oblivion, Polish-Jewish coexistence.

Słowa kluczowe: Stanisław Vincenz, Aharon Appelfeld, pamięć, Holokaust, zapomnienie, koegzystencja polsko-żydowska.

In the notes of Irena Vincenz dated 1954, we read the following words from her husband's letter to his friend Marian Heleniak:

Dzięki serdeczne za pamięć od Was, choć jesteś trochę znieruchomiony, ale pamięć to wszystko. Dante Alighieri umieszcza na szczycie góry czyśćcowej dwa strumienie: jeden nazywa się Lethe - zapomnienie i służy do pochłonięcia tego, co w pamięci jest męczące, a drugi Eunoe - życzliwy zamysł, przecedza to, co najlepsze w naszej pamięci i zachowuje na zawsze. Życzę Ci, mój miły, aby u ciebie przeważyła i zwyciężyła Eunoe! 
[Thank you so much for remembering (us) even if you are quite immobile, but memory is all. Dante Alighieri places two streams at the top of the purgatory: one is called Lethe-'forgetting,' and serves to absorb memories which are difficult; the other, Eunoe, meaning a 'friendly idea,' filters all that is best in our memory and saves it forever. I wish for you, my dear, that in your case Eunoe prevail and conquer!]. ${ }^{1}$

\section{Memory in literature}

One of the main working tools of a writer creating a literary work is his or her memory. The personal experiences or experiences passed to him or her by other storytellers become the raw material for an author's work. A story is based on a selection of elements chosen to be remembered, in contrast to those consciously or unconsciously forgotten. Missing details which are not remembered, or are remembered only vaguely, or details passed on to the writer only partially, are completed by the writer's imagination, which may be seen as a writer's second—or, some say, first— tool.

Here I present some subjective memories of two writers, Stanisław Vincenz (1888-1971) and Aharon Appelfeld (1932-2018), who both use silence in their works as a tool to express their attitude toward the Holocaust. In the case of Appelfeld, a Jewish child during the years of World War II, personal silence related to his direct experience of Holocaust. Vincenz, by contrast, was an adult Polish intellectual who spent the war time in Hungary in poverty but in a relatively safe environment; he experienced the Holocaust indirectly as he observed the situation of European Jews through the eyes of his many beloved friends. By 'silence' I mean the act of conscious forgetting; in other words, a conscious selection of recalled memory. I will show that interpreting a literary text in the context of the meaning of silence is important, and perhaps valuable for the study of history, as it allows a merger of literary and historical research.

In his monograph, Michał Kaczmarek analyzes the problem of memory in Stanisław Vincenz's work. In the introduction he points to the fact that a writer typically thinks and creates only through memory. ${ }^{2}$ This statement rests on the assumption that elements of fiction which are not

${ }^{1}$ Irena Vincenzowa, "Rozmowy ze Stanisławem Vincenzem 22 III 1954," Regiony (1993), 2:138. All quotations from Stanisław Vincenz's texts and from other Polish texts were translated into English by the author of the paper.

${ }^{2}$ Michał Kaczmarek, Proza pamięci: Stanistawa Vincenza pamięć i narracja (Toruń, 2009), 23. 
among the writer's autobiographical experiences but are transmitted to him by others, heard or read in other sources before they are transformed into a literary text, are first inscribed in the writer's memory. Kaczmarek underscores that "Writer's memory is a text-generating element of the literary creation. It is also a sphere where in an invisible way truth mixes with fiction. In this sense, memory resembles literature." ${ }^{3}$

Obviously, this is not the way that history works, and the problem of memory is more intricate. This topic was particularly interesting and inspiring for Paul Ricoeur, who created the term the "narrative memory" (récits de mémoire), reserved for different ways of presenting the past. Ricoeur's narrative memory is defined as spoken, common, colloquial narrations, individual and collective. The French philosopher contrasts the narrative memory with historical narrations, each of which has a different way of depicting the past, although this does not mean that they lack an element of memory altogether. Kaczmarek points out that narrative memory can be transferred to the field of literature. Literary narrative memories differ from historic ones, meaning that the status of a memory item is different, its horizon is narrower, its depicted experience is subjective; all these are contrasted with the historical object, which is able to capture an objectively wide horizon of past times and space. ${ }^{4}$ Therefore, in the literary field, memory's selectivity should not be deemed a flaw.

\section{Manipulation of memory}

An inexhaustible topic regarding narrative memory in the literary context and in the problem of manipulation of memory is often present in postHolocaust texts. This is because the traumatic memory, in its individual and collective aspects alike, has been and continues to be widely described and documented, continuing to be an inspiration for numerous works of literature and art. As it was one of the most traumatic collective experiences of twentieth-century Europe and has been extensively documented historically, subjective descriptions of the Holocaust events can readily be juxtaposed onto more objective ones. Monika Woźniak presents the problem of manipulation or selectiveness of memory based on early Polish post-Holocaust literature. She shows how the memory of a younger

\footnotetext{
${ }^{3}$ Ibid.

${ }^{4}$ Ibid., 33.
} 
audience that does not recall the Holocaust is formed instead by whatever documents and other materials remain. Hence, the literary depiction of Auschwitz differs from the historical one. Woźniak cites three examples from Polish literature: Janusz Nel Siedlecki, Krystyn Olszewski, and Tadeusz Borowski, Byliśmy w Oświęcimiu [We Were in Auschwitz], 1946; Seweryna Szmaglewska, Dymy nad Birkenau [The Smoke over Birkenau], 1945; and Zofia Kossak-Szczucka, Z otchtani [From the Abyss], 1946. She notes that the three books present the Auschwitz concentration camp not as an extermination camp, as they describe the extermination of Jews from the outside. Furthermore, she highlights the tendency to avoid speaking about the awkward and controversial aspects of Polish-Jewish relations in pre-war Poland. Therefore, the whole picture emerging from the three books is partial and one-sided, lacking historical reliability. ${ }^{5}$

As mentioned, Ricoeur's narrative memory in the literary context assumes its selectivity - a feature unacceptable in historiography; however, literature is indeed an individual, subjective interpretation of past reality. Does this mean that it lacks any historical value? Perhaps instead of judging the literature's truthfulness, we should include the literary depiction of reality as yet another tool in the process of historical interpretation.

Glenda Abramson describes three different plays about the same historical event. An unsuccessful attempt to save Hungarian Jews by Dr. Rudolf Kastner during World War II inspired writers to produce various-sometimes contradictory-interpretations. Abramson points to the artificial separation of history and literature. In referring to three plays-Motti Lerner's Kastner, 1985; Jim Allen's Perdition, 1987; and Heinar Kipphardt's Joel Brand: Die Geschichte eines Geschäfts [Joel Brand: The History of a Business Deal], 1965-she observes that documentary drama is selective, as it applies a "high degree of manipulation" in its view of history, sometimes adding a precarious combination of moral didacticism and historical interpretation. However, with regard to Kastner, history has already been manipulated. ${ }^{6}$ The trial transcripts and other materials

${ }^{5}$ Monika Woźniak, "Embarrassing Problems Connected with Polish Concentration Camp Literature," in Elrud Ibsch (ed.), The Conscience of Humankind, Literature and Traumatic Experiences (Amsterdam-Atlanta, 2000), 133-142.

${ }^{6}$ Rudolf Kastner was a Hungarian Jew who in 1944, to save thousands of Jews from deportation to the death camps, collaborated with Nazi Germans. The dilemma concerns the number of Hungarian Jews he could have saved by informing them of the true destination of the deportations, and his speaking in defense of a few Nazis at the Nuremberg trials, which contributed to the exoneration of one of them, Kurt Becher. Kastner himself was tried in Israel in 1955, and assassinated in 1957. A year later the Israeli Supreme Court 
underlying the plays are therefore unreliable. Memories were distorted, people during the trial deliberately lied, and even the participants in the tragic tale did not know the truth about the upheavals of the time. Abramson concludes:

It is therefore not difficult for a creative writer to fill in the gaps. Many contemporary philosophers of history question the ability of history to reveal absolute truths, and they therefore resist what they believe is the artificial separation of history and literature. They support the post-modern blurring of the boundaries between history and fiction. ${ }^{7}$

Abramson further explains the meaning of the artificiality of the separation of history and literature, and calls upon the work of Susana Onega. This literary researcher in her introductive text analyzes the term "historiographic metafiction," reviews history from the Renaissance, and goes even earlier-to antiquity, when history and literature were treated as one discipline. Describing the development of this topic throughout the ages, presenting views of the great philosophers, Onega follows the thought of another scholar, Linda Hutcheon, that history and literature have completed a full circle of separation to become one again:

As a conclusion we may say that the contemporary creative writer becomes a historian in an attempt to fill in the gaps left by the traditional totalitarian history while at the same time the philosophers of history try to achieve the same aim through the exploration of the narrative mechanisms of history-writing. Thus, the tendency to separate literature and history that has been traced back to the Renaissance may be said to have come the full circle to the point where both must be united again even if as kindred narrative forms, as human constructs, . . . However, a doubt still remains: how can historiographic metafiction be truth-revealing without losing its condition of human construct without aspiring to provide overall categorical answers? ${ }^{8}$

Abramson resolves the problem of uniting literature and history while continuing her discourse on the three texts about the Kastner case:

cleared Kastner of most of the accusations. See Leora Bilsky, "Judging Evil in the Trial of Kastner," Law and History Review 19 (2001), 1.

7 Glenda Abramson, "The Cultural Uses of the Holocaust," in Ibsch (ed.), The Conscience of Humankind, 22.

${ }^{8}$ Susana Onega, "A Knack for Yearns: The Narrativization of History and the End of History," in ead. (ed.), Telling Histories: Narrativizing History, Historicizing Literature (Amsterdam-Atlanta, 1995), 16. 
Our three playwrights have done just this. However: can the plays whose narrative they have so constituted be read as history? This is a dangerous formulation, particularly with regard to charged topics such as the Holocaust. Can we reject entirely the "traditional privileges of history over story?" Is it so that in order to remain faithful to what is termed the "post-modern ethos" the attempt to construct an objective truth of history must be abandoned? Many theorists and philosophers of history seem to worry about history being represented as fiction. When considering the Holocaust, we have also to worry about fiction being represented as history. ${ }^{10}$

I agree with Abramson that treating fiction as a historical document might be risky, even if such an approach almost imposes itself when we deal with fiction written as memoirs, diaries, or other genres, in which we are confronted with realistic, historically confirmed places and eventsthe aforementioned narrative memory. As a possible solution to this problem it may be assumed that such fiction is not directly an important part of history, but is a supplement. In that case, the informative value of fiction should be its literacy and textuality, but also everything beyond which belongs to its interpretation. In the case of historical interpretation, important questions should include how the literary material was retrieved and selected from memory, what was left to be forgotten, and why. Admittedly, in a historical interpretation the person of the writer becomes an important part of his or her creation.

\section{The same place, different narrations}

In order to understand better the meaning of historiographic metafiction in modern literature, I shall look more closely at selected works by the Polish writer Stanisław Vincenz (his essays and tetralogy Na wysokiej połoninie [On the High Uplands $]^{11}$ ) and of the Israeli writer Aharon Appelfeld (his novels: Kol asher ahavti [All Whom I Have Loved], Ha-ktonet ve-ha-pasim [Tzili: The Story of a Life], and Sipur chaim [The Story of a Life]). ${ }^{12}$ Based

${ }^{9}$ Ibid., 17.

10 Abramson, "The Cultural Uses of the Holocaust," 23.

11 The English title comes from the sole translation into English of extracts of the first volume of Vincenz's tetralogy. Stanisław Vincenz, On the High Uplands: Sagas, Songs, Tales and Legends of the Carpathians, trans. Henry Charles Stevens (London, 1955).

12 The spectrum of Appelfeld's works is very wide; he published over forty novels and his work is well described and researched. Among the meaningful studies devoted to Appelfeld are the following: Lily Rattok, Bait al blima: omanut ha-sipur shel A. Appelfeld (Tel Aviv, 1989); Yigal Schwartz, Omanut ha-sipur shel Aharon Appelfeld (Or Yehuda, 2014); 
on these works, it would seem that the prose of one has little in common with that of the other; however, the two are connected by the place they both describe in their fiction and also partly by the period they write about. The place could generally be defined as the Eastern Carpathian Mountains, a region which between the two world wars belonged to Poland and Romania (Bukovina). The authors mention the actual names of places, for example, the towns Kołomyja, Czerniowce/Czernowitz, Stryj, Słoboda Rungurska, and Wierbiąż; likewise, they mention the river Prut. The two authors were born relatively close one to the other-in towns some 100 kilometers apart. Although born in different times (Vincenz in 1888, Appelfeld in 1932), they experienced similar surroundings in the Eastern Carpathian Mountains. As children they absorbed similar landscapes, smells, and tastes which became engraved strongly in their memories. They both experienced the trauma of losing their home, the safe and familiar place, and were forced to wander around Europe. However, their private histories differ dramatically. Vincenz, the older of the two, experienced living in the Eastern Carpathians for a longer period, as he left the region when he was already more than fifty-years old. In 1940 he left his house and escaped, first to Hungary, ${ }^{13}$ and later, after the war, settled in France and then Switzerland, where he died in 1971. Vincenz wrote most of his works when living in the Alps, although most of his themes are set in his motherland. Aharon Appelfeld underwent completely different experiences. He was just a young boy when World War II started; soon after, he lost his mother and later became separated from his father for many years. Before reaching Israel he had spent only about fifteen years in the Eastern Carpathians and other parts of Europe, half of them the years of the war and the Holocaust.

Although the memory perspective of the two authors seems to be completely different, they share a few important similarities. Both wrote

Avi Sagi, Avidov Lipsker (eds.), 24 kri'ot be-kitvei Aharon Appelfeld (Tel Aviv, 2011). In the present article the author refers especially to one specific novel of Appelfeld (All Whom I Have Loved) in order to stress particular details common both to Vincenz and Appelfeld.

${ }^{13}$ The family of Vincenz left their Carpathian home secretly one spring night of 1940. First the two sons of Vincenz left, later he and other members of the family followed. They went by foot, crossing the mountains toward Hungary. After several sometimes lifethreatening events they found their rescue. They spent the years of the war first in Budapest and later in Nogradveroce, as it was already too late to move further to the west of Europe. Hungarians were friendly to the Vincenz family; Stanisław had many friends there, yet they spent the years of the war in constant fear, ready to escape at any moment. See Mirosława Ołdakowska-Kuflowa, Stanistaw Vincenz: Biografia (Lublin, 2006), 208-220. 
their prose (or most of it) in the post-war period; both were strongly influenced by the Holocaust; and both had similar memories of nature and of the ethnic diversity of the Eastern Carpathians.

\section{Stanisław Vincenz}

Stanisław Vincenz is sometimes called the "humanist of the twentieth century," as he engaged in the most important themes of modern times (folk culture, tradition and identity, dialogue, myth and religiousness, propaganda, totalitarianism, the Holocaust, violence, or Gandhi's teachings), while constantly drawing on the heritage of European culture (Homer, Plato, the Bible, Dante, Cervantes, Goethe). He was a writer rooted in the peripheral Eastern Carpathians, where Poles, Ukrainians, Jews, and Armenians lived side by side, where languages and religions mixed, where traditions and forms of spirituality merged. As an émigré (from 1940 in Hungary and after the end of World War II in France) he occupied a central position in the circle of intellectuals debating the values constituting the foundations of Europe. This circle, centered on the Paris-based Polish periodical Kultura, consisted of Swiss, Jewish, and German intellectuals, members of the Greek Catholic clergy, and émigrés of the Ukrainian diaspora.

Vincenz's attitude and work are unique because of their profound attention to the religion, philosophy, tradition, and culture of the Jewish community, especially the spirituality of Hasidim. In view of the complex Polish-Jewish relations Vincenz, called the friend of the Jews, was a proponent of tolerance and peaceful coexistence. After the war he devoted considerable parts of his writings to Jewish topics and undertook it as his lasting moral duty to write about his perished friends, neighbors, and compatriots.

Stanisław Vincenz presented Polish-Jewish and Hutsul-Jewish coexistence in his pre- and, especially, post-war writing by selecting subjectively chosen details. He did so consciously, knowing that his depiction was remote from being an objective description of the far more complex reality.$^{14}$ In his writings about Polish-Jewish and Hutsul-Jewish relations, we can distinguish three groups of themes: essays describing the interwar period; mutual relations in the Eastern Carpathians countryside in the

${ }^{14}$ Dorota Burda-Fischer, Stanisława Vincenza tematy żydowskie (Wrocław, 2015). 
nineteenth century presented in the plots of his main work - the tetralogy $\mathrm{Na}$ wysokiej połoninie (henceforth called Połonina); and Hasidic stories belonging to the same work.

Vincenz wrote several essay-memoirs on Jewish themes. Generally, they describe people such as the poet Nuchim Bomse, ${ }^{15}$ or are responses to various publications, including a book by Samuel Scheps, ${ }^{16}$ a review of Stefania Zahorska's book, ${ }^{17}$ or a text to mark the anniversary of the massacre of the Jews of Kołomyja. ${ }^{18} \mathrm{He}$ also wrote a collection of essays entitled Dialogi lwowskie [Lwów Dialogues] 1959, Karol Kuryluk, Poland's former Minister of Culture, encouraged Vincenz to prepare a text about the artistic and intellectual scene in Lwów during the 1930s (now Lviv in Ukraine) for an anthology he was editing. ${ }^{20}$ Vincenz decided to present the intellectual life of the city, which according to him was characterized by coexistence, a special mixture of people (free of xenophobic feelings) whose main "religion" was science and culture. That group of texts is titled "dialogues," as they describe meetings of Lwów intellectuals in a situation of speaking together. Vincenz emphasizes the Jewish origin of some of his heroes and their natural merging into the society. Their Jewishness is somehow important, but even more important are the conversations about mathematics, philosophy, theater, literature, history, and politics. The picture of cosmopolitan coexistence is highlighted by an anecdote. Most of the dialogues described by Vincenz take place in "salons"-usually regular meetings of people of intellectual and artistic

${ }^{15}$ Stanisław Vincenz, "Poeta srebrnych kwiatów," in id., Tematy żydowskie (Gdańsk, 1993), 71-81.

${ }^{16}$ Stanisław Vincenz, "Mickiewicz i Żydzi," in id., Tematy żydowskie, 63-70.

${ }^{17}$ Stanisław Vincenz, "Ofiara Stefanii Zahorskiej," in id., Tematy żydowskie, 90-96.

${ }^{18}$ Stanisław Vincenz, "Ofiary w Kołomyi," in id., Tematy żydowskie, 56-62.

${ }_{19}$ Stanisław Vincenz, "Dialogi lwowskie," in id., Po stronie dialogu (Warsaw, 1983), 2:95-194.

${ }^{20}$ Karol Kuryluk (1910-1967) was a Polish journalist and publisher; before the war he established Lwów periodical Sygnaty (1933-1939) and after the war Odrodzenie (19441948); he was a cultural activist and a Minister of Culture (1956-1958), and also an ambassador to Austria (1959-1964). While being a director of Państwowe Wydawnictwo Naukowe (National Scientific Publishers PWN), he unwillingly got involved in an antisemitic campaign in Poland in 1968. His publishing house printed in the Wielka encyklopedia PWN [Great PWN Encyclopedia] a note regarding the number of Jewish victims in concentrations camps-details which were not following the general line of historical politics of the communistic leadership, promoting Polish martyrdom during World War II. This note, regarded as dissent, was an excuse to dismiss a number of the people from the publishing house, which was a part of many other antisemitic actions undertaken by the Polish government against Jewish citizens at that time. Privately, Kuryluk saved his wife during the Holocaust. Ewa Kuryluk, Kangór z kamera (Kraków, 2009). 
circles, in private houses of certain hosts. He gives details about a few such salons. One anecdote occurred in the salon of Mrs. Lusia Meisels. ${ }^{21}$ It transpired that after Nazi Germany annexed Austria, the novelist Joseph Roth, a native of Brody, found himself in Lwów. Because he was a celebrity, he was invited to Meisels's salon, where Vincenz and nearly all the characters described in Dialogi lwowskie appeared. For some reason Roth assumed that all the guests present at the party were Jews. His mistake was left uncorrected for a long time, but the party burst into laughter when he started a conversation with Dunin-Borkowski ${ }^{22}$ (an aristocratic Pole) with the words, "Being a Jew you must agree [that] with your appearance you couldn't walk in Vienna freely." Jokes about the adjectives Jewish and Aryan ensued. Vincenz describes the scene: "the mood was virtually euphoric, but Roth, full of emotion, remarked, 'Dear friends, I assure you that you are enjoying the last party of this kind in Europe'."23

Reading Dialogi lwowskie and other essays describing Polish-Jewish relations, one hardly encounters information about conflicts: the Lwów pogrom in 1918 is barely hinted at. Vincenz does not say that it did not happen; he simply chooses not to talk about it. Here are his words in a letter to Kuryluk after he was invited to write about Lwów:

Ach, mój panie Karolu, redaktorze, a raczej animatorze tych wspomnień. Taki pan był zawsze czupurny, iż mówiło się czasem na kogoś innego: „taki czupurny, jak sam Karolek”. A teraz zachęcając mnie, ostrzega pan równocześnie trwożliwie, aby nie robić ze Lwowa „utraconego raju”... Według Dantego Bóg nie jest ograniczony do raju, a raj nie jest w przestrzeni . . . I Lwów nie jest w przestrzeni, gdzieś z tamtej strony Sanu, ani nie ogranicza się do okresu lat przedwojennych czy innych. Lwów to zamiar, obietnica i możliwość. I po co ich się wypierać? Zażydzając na nowo tę straszliwą dla nas pustkę, idę mimo woli śladami Dantego Alighieri, który tak zaludnił dziedzicznie najwyższe regiony raju patriarchami, prorokami, a nawet niewiastami żydowskimi. Czynię to nie dlatego, jakobym był powołany, ale właśnie z obawy, że powołanych już nie stało. Natomiast wbrew przykładowi Dantego staram się jak najmniej zatrącać o piekło, tak jakby nie było dziedziny Kainów.

[My dear Mister Karol, dear editor, or should I say my memory animator: you have always been so pugnacious that we would always say about other people, "This one is nearly as pugnacious as our Karol." Alas, much as you encourage me now, you also passionately warn against making Lwów a "Paradise Lost." . . A According to

${ }^{21}$ Stanisław Vincenz, "Koniec świata," in id., Po stronie dialogu, 2:178-189.

22 Piotr Dunin-Borkowski (1890-1949) was a Polish politician, conservative activist, voivode of Lwów, and an outstanding specialist on Polish-Ukrainian relations.

23 Vincenz, "Koniec świata," 188. 
Dante, God is not limited to paradise, and paradise is not restricted to any space; . . . for Lwów is not just some space somewhere on the other bank of the San River, nor is it restricted to the pre-war era or to other times. Lwów is an intention, a promise, an opportunity. And why deny it? By repopulating this awful emptiness with Jews, I follow instinctively in the footsteps of Dante, going upstream, as he populated the highest echelons of paradise with patriarchs, messiahs, and even Jewish matrons. I do not do this because I feel I have a calling, but for fear there might be no other people left who do have a calling. On the other hand, I disclaim Dante and I'm trying to avoid hell as if the domain of Cain did not exist]. ${ }^{24}$

Similarly in Potonina, the work which presents life in the Eastern Carpathians countryside, Polish-Jewish and Hutsul-Jewish relations are idealized (as if Vincenz were trying to avoid hell). ${ }^{25}$ The work, which contains many folk tales, presents heroes living their everyday lives in the mountains, adhering to the precepts of their various religions, and respecting each other. Vincenz grew up in this world, and therefore knew it very well. There are many examples showing understanding and respect between Hutsuls and local Jewish people. Each group respects the other's beliefs: Jews respect Christmas celebrations, Hutsuls respect the Jewish Shabbat, they invite each other to celebrations, such as the baptism of a newborn baby-where care is taken that the Jewish guests be served kosher food. They would sit together in the tavern and listen to each other. Hutsul people would come to the tavern to talk, declare their problems, and eat simple but excellent food, like the white rolls baked by old Rosa. ${ }^{26}$ Instances of such beautiful idyllic coexistence, with its roots in Hutsul legends, are numerous. One story relates that the mountain hero Dobosh once met the Baal Shem Tov on the mountain paths. They became friends and even shared mutual secrets, such as the hiding places of sacred books. ${ }^{27}$

More examples appear in the post-war volumes of Połonina. Eugenia Prokop-Janiec points out the difference between the first volume (the only one published before the outbreak of World War II) and the postwar edition, in which Vincenz added new Jewish motifs. ${ }^{28}$ This fact is

${ }^{24}$ Stanisław Vincenz, "Lwowscy kosmopolici," in id., Po stronie dialogu, 2:126-127.

${ }^{25}$ See the quotation above.

${ }^{26}$ Stanisław Vincenz, Na wysokiej połoninie: Barwinkowy wianek. Epilog (Warsaw, 1983), 4:200.

${ }_{27}$ Stanisław Vincenz, Na wysokiej połoninie: Prawda starowieku. Obrazy, dumy i gawędy z Wierchowiny Huculskiej (Warsaw, 1980), 1:247.

${ }^{28}$ Eugenia Prokop-Janiec, "Na wysokiej połoninie: Obrazy, dumy i gawędy z Wierchowiny Huculskiej: Motywy żydowskie wobec literatury Dwudziestolecia," in Mirosława Ołdakowska-Kuflowa (ed.), Stanistaw Vincenz - humanista XX wieku (Lublin, 2002), 273. 
understandable given the situation that the whole ethnically diverse and coexisting world which Vincenz cherished in his memory had now lost one of its ethnic groups. Vincenz never came back to the places of his pre-war world, therefore, one can only presume how difficult it was for him to imagine the Eastern Carpathians without Jews. Undoubtedly, only imagining it must have been a traumatic experience. Suddenly, the need to recall people and places became an important goal.

Vincenz's Hasidic stories contain fewer examples of mutual relations among Poles, Hutsuls, and Jews, as by definition the stories present the world of Hasidim, where Vincenz delves into Jewish mysticism. However, one tale, "Opowieść o Żydowskim Kamieniu" [The Story of the Jewish Stone], ${ }^{29}$ which notably describes a life that resembles the biography of the Baal Shem Tov, has a meaningful motif. The meaning of the story relates to the Holocaust and in an allusive way refers to the murdering of Jews by their neighbors. The young boy Jekely, looking for religious meaning in his life, decides to leave the town and its fusty Torah study classrooms. He takes his very young wife Rachel to the mountains, and there discovers the imposing presence of God. Surrounded by beautiful nature, he is inspired to worship the religion of all humanity, namely the religion of brotherhood and friendship. In almost an instant he is transformed from a lost young soul searching for the meaning of life into a conscious and devoted tsadik.

$\mathrm{He}$ and his young delicate wife Rachel settle in one of the mountain villages after being beautifully welcomed and hosted by the local people, especially one of them, an elderly man called Wasyluk. Jekely brings light to the local people; in exchange, he installs glass in their windows. His wife heals people and teaches them to heal themselves. For all that, the story ends tragically. When Jekely is away on one of his meditation retreats in the mountains, Rachel and the children are murdered by criminals from another village.

Vincenz belongs to the group of Polish Christian writers who touch on Jewish topics. But he differs from most of them by treating his topics painstakingly, going far beyond a shallow presentation of a social group and its culture. He presents not only Jewish customs but also the basics of Judaism. But he did not write only about Eastern Carpathian Jewry; he also presented other groups of the region with the same dedication,

${ }^{29}$ Stanisław Vincenz, "Opowieść o Żydowskim Kamieniu," in id., Na wysokiej połoninie: Barwinkowy wianek. Epilog, 4:305-355. 
emphasizing especially the common areas where cultures met, pausing at points where they merged.

However, Vincenz omitted difficult topics which could destroy the idyllic picture of peaceful coexistence-this omission could be attributed to his sense of mission to speak about the Jews. He mentions this openly in the above-quoted letter to Kuryluk. The following quotation expands this explanation; these are Vincenz's words to his wife regarding the essay about the origin of Hasidism:

Wiesz, jakie dałem motto do artykułu o chasydach? Nikt nie wie i nikt na pewno nie zwróci na to uwagi. Tobie mogę to zdradzić. Motto z Iliady - Achilles mówi: „Abym natychmiast umarł, bo nie było mi dane ochronić towarzyszy zabijanych”. [Do you know what motto I gave to the article about the Hasidim? No one knows and probably no one will notice. But I can reveal it to you. It's a motto from The Iliad-Achilles says: "Let me die immediately, as I was not able to save my companions who were killed." ] $]^{30}$

Vincenz saves his companions/countrymen by cherishing their memory and by keeping a record of their traditions and habits, the signs of their existence. He does so by applying his deep knowledge of Hasidism and of Judaism in general, and also through his intimate experiences and memories reaching back to his childhood. ${ }^{31}$ Henryk Grynberg perceived the collection Tematy zydowskie $e^{32}$ exactly in that context in his review:

Z książki tej zapamiętajmy również podaną w Samaelu definicję Boga: ,jedyny jest pamięcią wśród wszystkich zapomnień świata”. Oznacza to, że pamięć zbliża nas do boskości. Vincenz każe nam pamiętać. $2: 16$.

${ }^{30}$ Irena Vincenzowa, "Rozmowy ze Stanisławem Vincenzem 8 I 1960,” Regiony (1995),

${ }^{31}$ In Spotkania $z$ chasydami [Meetings with Hasidim] Vincenz mentions one of his strongest childhood experiences: watching Jews praying on the Day of Atonement (Yom Kippur). He returns to this memory periodically in his literary oeuvre: here is a version found in his wife's notes: "Wycieczka na Jean Collet z Zarembami. Nad potokiem odpoczynek. Staś mówi: nigdy nie czułem tak potęgi modlitwy, jak w chasydzkiej bożnicy w Kołomyi. I przed laty w Jasienowie. Niańka ciągnęła mnie za rękę, a ja nie chciałem iść, tylko stałem przy oknie i patrzyłem, nie mogłem się oderwać" [The excursion to the Jean Collet (mountain peak - D.B.-F.) with the Zarembas. Resting by the stream. Staś says: I've never felt the power of prayer as strongly as I did in the Hasidic prayer house in Kołomyja. And many years ago in Jasienowo. My nanny was pulling my hand, but I didn't want to leave, I was standing by the window and watching, I could not part from this view]. Irena Vincenzowa, "Rozmowy ze Stanisławem Vincenzem 6 IX 1953," Regiony (1993), 2:120.

32 The collection of works by Vincenz relating to the Jewish topics, published post mortem by his wife and son. Stanisław Vincenz, Tematy żydowskie (London, 1977; Gdańsk, 1993). 
[From this book we will also remember the definition of God presented in "Samael": "the one is a memory among all the forgetting of the world." It means that memory brings us near to God. Vincenz orders us to remember. $]^{33}$

Vincenz orders us to remember culturally diverse nations that lived together in harmony. The predominant topic of the Jewish themes in his essays and in Polonina is cosmopolitanism. The following note, writtenhow ironic-during World War II, shows how important this idea was to him:

Narody nie muszą mieć i nie mają granic twardych. Wchodzą jedne w drugie, przesiąkają, przechodzą stopniowo jedne w drugie. Takim przejściem od Polski i Słowiańszczyzny do Rumunii jest Bukowina.

[Nations don't need to have and they haven't solid borders. They enter one into another, infiltrate, and gradually bypass each other. Such a passage from Poland and the Slavic land to Romania takes place in Bukovina. $]^{34}$

The author knows that this is not a true picture, yet he continues to draw it, though he cannot escape actual reality. By touching on the Jewish topics in Połonina and in his essays, he is bound to tell of the Holocaust. He does so very subtly and indirectly when he talks about the murder of Rachel and her children or the Lwów intelligentsia, ignoring the voices of the uneducated masses who fear Hitler even before World War II (Gtos spoza dialogó $w^{35}$ [Voice from beyond the Dialogues]). Yet in looking at Vincenz's oeuvre as a whole, one must see the incongruence of the idyllic picture of Jewish-Polish-Hutsul coexistence in Potonina or the harmonious Polish-Jewish symbiosis of the intelligentsia in Dialogi lwowskie with the catastrophe of World War II.

\section{Aharon Appelfeld}

The Israeli writer Aharon Appelfeld was born in 1932 in Jadova, a village close to Chernivtsi/Czernowitz, which at that time belonged to Romania; presently it is part of Ukraine. He was just a young, seven-year-old boy when World War II started. The war was extremely traumatic for him, as in 1941 his mother was killed during fighting between the Soviets who occupied the region and the Romanians who tried to recapture it. Young

${ }^{33}$ Henryk Grynberg, "Forma pamięci," Kultura (1978), 6:138.

${ }^{34}$ Stanisław Vincenz, Outopos: Zapiski z lat 1938-1944 (Wrocław, 1992), 19.

35 Stanisław Vincenz, "Głos spoza dialogów," in id., Po stronie dialogu, 2:175-177. 
Appelfeld was deported with his father to the Nazi concentration camp in Transnistria. After managing to escape, separated from his father, he wandered from village to village across Ukraine with a variety of displaced people. In 1946, at the age of fifteen, Appelfeld reached Israel (after spending several months in a refugee camp in Italy) in the framework of Aliyat ha-No'ar (the Jewish Agency's Youth Aliyah [immigration] Department).

Memories of such a traumatic and tragic childhood undoubtedly influenced the works of the writer. The plots, which could evince his own childhood experience, acquire special meaning in light of Appelfeld's explanation about why he did not write an autobiography: "Anyone who underwent the Holocaust will be as wary of memory as of fire. . . People learned how to live without it the way one learns to live without a limb of one's body. ${ }^{36} \mathrm{He}$ said that after writing an autobiography he would be unable to write additional novels thereafter; his memory would be exploited, incapable of pouring more fuel onto his imagination. Deepening the relation between memory and imagination, he described the strange relationship he and other Holocaust survivors had with memory, as their most important goal was to achieve the contrary: forgetfulness and loss of traumatic memories.

Commenting on the above quotation of Appelfeld, Leslie Epstein observes: "Naturally enough, among this remnant the need to think and write about what had befallen them could not be repressed. But how to do so? The disproportion between the events themselves and the means to express them was too great." ${ }^{37}$ Appelfeld reached his own way of expression through the process, writing "memory itself proved to be the enemy of my writing. ${ }^{.38}$ Epstein presents the full picture of Appelfeld's approach:

But when he turned to imagination, his poetry and fiction consisted mainly of sentimental excess and cries to God. Caught between a memory that failed him and an imagination he could not trust, he came to the turning point when he stopped writing about himself and instead focused on a Jewish girl with similar experiences. ${ }^{39}$

${ }^{36}$ Leslie Epstein, “'Child of His Time,' Holocaust survivor Aharon Appelfeld, Israel's greatest living writer and author of the new 'Until the Dawn's Light,' retains his capacity for wonder," an on-line article based on a lecture delivered at the International Conference on the Life and Work of Aharon Appelfeld, held at the University of Pennsylvania on 26 and 27 October 2011. http://www.tabletmag.com/jewish-arts-and-culture/books/83325/child-ofhis-time [retrieved: 8 June 2019].

37 Ibid.

${ }^{38}$ Ibid.

${ }^{39}$ Aharon Appelfeld, Tzili: The Story of a Life, trans. Dalya Bilu (New York, 1983). 
"Miraculously, as though with a magic wand, my compulsive memory was removed" and in its place came a redefinition of memory itself: not so much recollection, or thoughts that could be put in words, but certain sights, sounds, smells, colors, sensations, what, significantly, Hoffmann called "quickly changing pictures and impressions." Then, in the place of actual memory came the freedom to experience, or re-experience, what we can call privileged moments: something as simple, Appelfeld tells us, as a few twigs floating on the surface of a pond, the sun on them, the way they shiver in the wind and turn, and turn again, on the current. In such moments, and in their recollection, one may undergo a feeling of enchantment that Appelfeld calls "true memory," or "inner memory," or "a warm emotion." ... Once in possession of "inner memory," Appelfeld was able to write not "what happened but what had to have happened." That is say, his work, moved from history to art. ${ }^{40}$

As mentioned above, Appelfeld's oeuvre is very rich, comprising over forty novels; his works were published and translated regularly ${ }^{41}$ nearly until the end of his life $\mathrm{e}^{42}$ and gave raise to numerous scholarly publications. ${ }^{43}$ Contrary to Appelfeld, Vincenz wrote just one book ${ }^{44}$ over most of his life. It was Potonina, which was published only partly during his lifetime. Clearly, there are many differences between both authors, and also many ways to compare their works. Each novel of Appelfeld may serve as a different punctum Archimedis highlighting different aspects in Vincenz's work. In the present article, I chose Appelfeld's novel All Whom I Have Loved..$^{45}$ This work shares several motifs with Vincenz's works, among them similar landscapes in the Eastern Carpathians, descriptions of their ethnic diversity, and some elements of Jewish mysticism. Both novels present perspectives of experienced and rather mature authors.

In All Whom I Have Loved, the Carpathian natural landscape is as powerful as it is in Vincenz's novels. However, Appelfeld's is less mystic and has a more personalized meaning, related directly to the subjective experience-in fact, a child's experience, as the narrator of the novel is a nine-year-old boy. Accordingly, the river Prut appears in the story several times and its depiction reflects the narrator's emotions at certain moments. In one part of the novel, the river is loud, powerful, and scary as

${ }^{40}$ See: Epstein, "Child of His Time."

${ }^{41}$ At least twenty seven Appelfeld's novels were translated into English. Many were translated into numerous other languages.

42 Appelfeld died in January 2018, his last book-titled Timahon-was published in 2017.

${ }^{43}$ See n. 12.

${ }^{44}$ Vincenz wrote more works; however, the four volumes of Polonina were the ones he was writing and correcting till the last days of his life.

${ }_{45}$ Aharon Appelfeld, All Whom I Have Loved, trans. Aloma Halter (New York, 2007). 
the narrator describes it when living in a rented room with his father. The vast river is just behind the room's window and its description reflects the hero's feelings of being betrayed and abandoned by his beloved mother. The powerful river gives him strength to cope with difficult emotions. But earlier in the novel, the portrayal of the river is quite different: it is an idyllic picture of flowing water connecting all the elements of the landscape and, in a motherly way, embracing everything nearby, including the hero himself. The following excerpt could be taken from a fairy tale:

The village is all woods and fields, and streams from the River Prut that winds through them. Mother rented the house next to the water; she unpacked the suitcase and put on her green dressing gown. I stood at the window and saw no trace of streets, only children and sheep and horses galloping over the green fields. ${ }^{46}$

The river and the surrounding landscape stimulate a feeling of safety, just as the mother's presence comforts a child. But not only visual details represent this feeling of safety: the narrator also mentions tastes, e.g. the taste of delicious food he ate: "Mother's dishes were so tasty that I ate and ate and asked for more." ${ }^{47}$ Vincenz's writings contain several detailed descriptions of food served at parties in Hutsulian homes, but also in local taverns - one of them already mentioned: the Jaworowo tavern run by a Jewish family, where old Rosa's white rolls were served. ${ }^{48}$ So "food sentiments" appearing in both novels have the same significance, and area much deeper than just food flavors. These food memories express longing, and at the same time the need to remember what has passed, including details even as fleeting as taste.

Appelfeld pays attention to the wisdom of the local Carpathian population. As a young child speaking in the novel, he is full of admiration for the atavistic wisdom of Ruthenians. The boy's nanny, the Ruthenian girl Halina, told him about the God and about His presence in everything around. This was an overwhelming revelation, especially since neither of the boy's parents believed in God or could teach him any religious mysteries. The girl was wonderful in the boy's eyes: wild, intelligent, knowing life, feeling nature, acquainted with the language of birds and communicating with them: "Her thoughts were usually on birds; they were not afraid of her, and they would come to peck seeds from her palms. She would stroke

\footnotetext{
${ }^{46}$ Ibid., 7.

47 Ibid., 8.

48 See: Prokop-Janiec, "Na wysokiej połoninie," 273.
} 
them and speak to them, and put them on her shoulders. They were in no hurry to fly away." 49 The motif of the significant nanny, who influences a person's entire life, conveys to him/her the deepest secrets of the world like the perception of God and His creation, or the Ruthenian language, appears not just in Appelfeld's novel but also in the epilogue to Vincenz's Połonina. Small Siuna (Vincenz's alter ego) also recalls his nanny Pałachna, who taught him the Hutsulian language, but also introduced him to the Hutsulian culture, and gave him some important wisdom for life..$^{50}$

Appelfeld presents us with more Ruthenian heroes. He describes the aged owner of the room rented by the boy and his father, and his high esteem for Jews:

Strange, it was easier for me to talk with this Ruthenian peasant than with Father. The landlord told me about the Jews in the countryside who used to till their land like the Ruthenians, keeping God's commandments, not working on Sabbath, and giving to the needy. He seemed to miss them. "Is it good to be a Jew?" I asked for some reason. "It's a great privilege, my son. God spoke to the Jews at Mount Sinai and gave them the Torah. Since then the entire world knows that there is a God in heaven and that the world isn't up for grabs. You see?"51

But the mysteries of the Jewish religion are not passed on to the boy only by the Ruthenians. He experiences religion directly when he joins in Jewish prayers himself. At first he would shyly approach the praying Jews in the next-door yard and would be mildly afraid of the bearded Jews: "[They] seemed to have a secret, and to move this secret from hiding place to hiding place. When the secret was well hidden they went inside to pray. Their prayer was noisy and sometimes they shouted." 52 The most dramatic and expressive description of Jewish worship is related later in the novel, when the narrator recalls Yom Kippur and the sublime atmosphere encompassing that day. The Ruthenian neighbors participated passively in the Jewish festival: "Jews in white clothing hurried to the synagogue, and Ruthenian women stood leaning against the fences, watching them closely. Halina and I also stood next to our fence. Halina's face was serious, and I saw how the awe of this evening was upon her, too." ${ }^{53}$ And then comes the description of a long silence which affected the

\footnotetext{
49 Appelfeld, All Whom I Have Loved, 38.

${ }^{50}$ Stanisław Vincenz, "Kroniki stanicy górskiej," in id., Na wysokiej połoninie: Barwinkowy wianek. Epilog, 4:538.

${ }_{51}$ Appelfeld, All Whom I Have Loved, 120.

52 Ibid., 34.

${ }^{53}$ Ibid., 64.
} 
women watching and calmed them; only after that silence did the actual intense praying start. This worship, at first weeping and then "long and drawn-out sobbing, ${ }^{54}$ brings to mind the picture featured in Vincenz's writings. ${ }^{55}$ Both Appelfeld's and Vincenz's descriptions of Yom Kippur prayers present a child's fascination of the mysterious world of the grownups, whose world is full of secrets and rituals.

The motif of secrets can be read as a child's projection, but how meaningful it is in the context of the Holocaust! This context is more emphatic in a comment spoken by the innkeeper, who misses the Jews who used to live nearby, and also their religious practices. He tells the boy's father about past times when many Jews lived there, but their children had deserted their fathers' religion and moved away to the cities. The story continues:

Then he told Father about the festivals and customs of the Jews in this place. On the Day of Atonement all the men would wear white clothes, and they looked like creatures from another world. "It's a pity that they've left us" he added. When the boy's father asked if the real reason for Jews' leaving the area was not pogroms, the innkeeper says: The old Jews were used to pogroms. People beat them and they accepted their suffering with love. ${ }^{56}$

Appelfeld rarely speaks about the Holocaust directly; also antisemitism is usually barely mentioned, and the above example of a forthright remark about pogroms is an exception. However, there are brief, veiled allusions, like the narrator's description of a group of children passing by the summer home of the protagonist shouting "Jews! Jews!" Then follows this sentence: "The fields breathed quietly, and you could see the dark waves of night floating over earth. ${ }^{\circ 7}$ These seemingly minor incidents are replete with meaning, fueling massive atavistic fear. Shortly after describing the children's shouting, the narrator mentions "sensing danger." Characteristic of Appelfeld's novel is that his remarks about antisemitism lack any kind of judgment; neither blame nor justification is placed on those involved, as if the author presented only dry facts: anything that does not concern his nearest and dearest is presented from a distance. This is also seen in the motifs of the Rachel's tragic death in Vincenz's story about Jekely and also of Appelfeld's account of the death of the boy's father. In the latter, the main theme is the senseless killing of the boy's father. Who did it, and

\footnotetext{
54 Ibid., 65.

55 See n. 31.

${ }^{56}$ Ibid., 216.

${ }^{57}$ Ibid., 10.
} 
why he did it, is less important: the focus is placed entirely on the tragedy of a small boy and on the irony of the world in which the boy has to survive. In Vincenz's story, the senseless death of Rachel and her children is followed by the justification that those who committed the crime came from a different village. Later there is a trial-according to Vincenz, the last trial of its kind in the Carpathian Mountains, called "the court of an old age."

If Vincenz's Carpathians can be seen as a cradle of European spirituality and human values, the trial has universal meaning, which is the civilized way of judging evil. Thus, it is as if after this trial the evil would be expunged from the world forever. It goes even deeper, as the Jewish hero, husband and father of the murdered victims, sets the murderers free in a great act of forgiveness, revealing the triumph of human values.

The meaning of Appelfeld's story is different: it is much more personal. The abandoned person, left alone in the world, is a child, too fragile, innocent, and traumatized to think of the murderers. He concentrates on his tragedy and his loss, feeling absolute helplessness. Yet the child's despair in All Whom I Have Loved refers to a universal topic but also to the topic of the Holocaust. Gila Ramras-Rauch in her monograph on Appelfeld's work points precisely to this:

Appelfeld does not try to come to terms with the Holocaust in a confrontational manner. He does not pose the question of where the Jewish God was when his people were being massacred, and yet the very absence of the direct question points to the problem of phrasing it. Appelfeld chose not to write stories of lamentation and supplication, which most often assume the existence of an addressor and an addressee. He deletes two major factors in the traditional literature of destruction: the divine presence and the enemy. ${ }^{59}$

However, the novel seems to focus in particular on another major theme, namely memory, or rather selective memory. The child in the novel one by one loses everything and everyone who is important to him, whom he loves. He first experiences the parting of his parents, then the emotional distance of his mother, the death of the beloved nanny, the death of the mother, and, finally, the death of the father whom he only recently had learned to love and understand. These events shape the way he remembers: by recollecting only selected parts of the reality. The narrator distinctly mentions the wish to remember certain moments,

58 Vincenz, “Opowieść o Żydowskim Kamieniu,” 338.

${ }^{59}$ Gila Ramras-Rauch, Aharon Appelfeld: The Holocaust and Beyond (BloomingtonIndianapolis, 1994), 30. 
impressions, or views, as if those carefully selected moments had some magical protective powers. When the hero's mother cannot recall her own parents clearly, the boy says:

"I will remember the house in the country and the water in the river. And the lake," I said for some reason. "And me? Will you remember me, too?" she asked, suddenly putting me to the test. "I'll remember you most of all." I wanted to impress her. ${ }^{60}$

Sometimes the narrator is terrified that he might forget:

I'm afraid that these clear images will be erased from my memory, and I repeat to myself: they won't be wiped away, they won't disappear, they will always be with me just as Mother will always be with me. But this very repetition stirs in me a deep sorrow that insinuates itself within me ... "I'm afraid that the village will disappear." "It won’t disappear," Mother says, and opens the door. ${ }^{61}$

Later he thinks of some techniques which could be used for him to recall better, as if he were in constant danger of forgetting important memories:

It's a shame that I didn't draw Halina when we were together. Had I done so, I could have kept her close to me. Now my memory plays tricks on me. Sometimes I feel like sitting and drawing what I see before me, so that when the time comes, my memory won't deceive me. ${ }^{62}$

Yet Appelfeld himself points to the important role of forgetting as a sort of condition for many Holocaust survivors to start a new life. He claims that many of them had to face a plethora of difficult choices as, for example: "whether to continue living with memory of the Holocaust or to start a new life." ${ }^{63}$ However, the decision to forget traumatic memories does not mean the decision to forget one's roots and birthplace. These two elements are crucial for the writer and he mentions them repeatedly. Appelfeld told Gila Ramras-Rauch that a writer needs a homeland, "and 'homeland' for him means the first formative experience in life: the first trees one observes, the first snow. For him the microcosmic homeland is Jadova and Czernowitz." ${ }^{\prime 4}$ In his autobiographic book he recalls his personal friendly meeting with the writer Shmuel Agnon, who told Appelfeld that "every writer needs to have a city of his own, a river of his own, and

\footnotetext{
${ }^{60}$ Appelfeld, All Whom I Have Loved, 15.

${ }^{61}$ Ibid., 23.

62 Ibid., 158.

${ }^{63}$ Aharon Appelfeld, The Story of a Life, trans. Aloma Halter (New York, 2004), 170.

${ }^{64}$ Ramras-Rauch, Aharon Appelfeld, 11.
} 
streets of his own." ${ }^{65}$ Appelfeld also mentions the meaning of homeland in All Whom I Have Loved. An example could be just a single sentence or rather a statement by the boy's father that everywhere outside Czernowitz is exile (he said this after he and his son returned from a rather long stay in Bucharest). Another example from the boy's father, just before the trip to Bucharest, appears in his words to his admirers who have gathered at the local inn: "Don't worry, I won't forget Czernowitz; this city is planted deep within my heart, and it will go with me wherever I go. A birthplace cannot be uprooted from the heart-even one that has been hard on you." ${ }^{66}$

In an interview, the writer admits that even as a child he perceived his home and childhood as a Garden of Eden. He recalls a beautiful home, bourgeois wealth, and the ease of living. Love of his parents, goodness, cultural life, and modern thought embraced this whole world. He distinguishes between two kinds of Gardens of Eden-one was the city with its culture, coffee shops, cinemas, and so on, and the other was the Carpathian Mountains with their unique nature and Jewish religiousness, which was fading away in the city. ${ }^{67}$ Zvi Zameret describes Appelfeld's creation as an attempt to reconstruct his long-lost home; however, this was for Appelfeld a desperate attempt, as it was doomed to fail. ${ }^{68}$

\section{The meaning of oblivion}

Vincenz's notes to the essay Po stronie pamięci [On Side of Memory]: "Pamięć może być także umyślnie formowana dla zamierzonego użytku" [Memory might be intentionally formed according to needs] ${ }^{69}$ might suggest that he manipulated memory in his works. Little is said about antagonisms, pogroms, "bench ghettos" at universities, or informing on Jews to Nazis by their neighbors. It is not possible that Vincenz did not know about all of it. Marceli Najder, younger than the writer, was born not far from the above places_-in Bolechów in 1914. As a young pharmacist in pre-war

${ }_{65}$ Appelfeld, The Story of a Life, 165.

${ }^{66}$ Appelfeld, All Whom I Have Loved, 136.

${ }^{67}$ Dror Mishani, "Bein Rechavia le-Mea Shearim," Ha'aretz (9 Sept. 2006).

${ }_{68}$ Zvi Zameret, "Appelfeld bein Czernowitz levein Jerushalaim," in Sagi, Lipsker (eds.), 24 kri'ot be kitvei, 17.

${ }^{69}$ Stanisław Vincenz, Uwagi o pamięci, Neapol, 25 June 1960, in Biblioteka Zakładu Narodowego im. Ossolińskich we Wrocławiu, collection: Archiwum Stanisława Vincenza, call no. 17550, p. 31 . 
Lwów, he kept a diary describing the times. ${ }^{70} \mathrm{~A}$ strong young man, recently married, he found himself together with his relatives in the Kołomyja ghetto. Working in a sanitary unit of the Jewish ghetto police, he could easily understand the danger of remaining in the ghetto; he escaped with his wife as soon as an opportunity presented itself. They hid together with a few other Jewish refugees in the nearby village property of a Pole named Andrzej Śliwiak. His diary documents one and a half year of hiding and suffering in bad hygienic conditions, with difficult social relations between the refugees themselves and the hosting Poles. He also mentions events outside his hiding place: the looting of Jewish homes by Ukrainians and Poles on 29-30 June 1941; or Jews murdered by their neighbors in the villages of Rungury, Słoboda Rungurska, Słobódka Leśna, and Otynia ${ }^{71}$ (some of these places are described in Vincenz's prose).

There is clearly no reason to assume that Vincenz had not heard about those events, especially because he was in touch with many people who had formerly lived in the Eastern Carpathians, including some Holocaust survivors. However, it is problematic to consider intentional manipulation in its negative sense. We deal with manipulation when certain events are deliberately omitted in order to hide inconvenient facts or stories. This is clearly described in a book by Elżbieta Janicka and Tomasz Żukowski, who analyze a documentary movie by Jolanta Dylewska titled Po-lin: Okruchy pamięci [Po-lin: Pieces of Memory $]^{72}$ and claim that a certain picture can be drawn in a way that generates a wholly new interpretation. In the film, happy Jewish citizens of a small town smile apparently at the viewers - a Polish audience, while these smiles and greetings of the movie heroes are actually directed at their American relatives who came to visit their old country homes at some time between the two world wars. Those relatives came from afar and made commemorative films with their amateur cameras. Dylewska used those very films in her documentary movie. Janicka and Zukowski point out that the director does not want to see the space where the real meeting between Jews and Poles took place. She does not mention that in the 1920s and 1930s the Polish state did not grant Jewish citizens equal rights. Quite common for that time, antisemitic acts are seldom mentioned in the movie. ${ }^{73}$ In

${ }^{70}$ The book was published post mortem. Marceli Najder, Rewanż (Warsaw, 2013).

${ }^{71}$ Ibid., 10.

${ }^{72}$ Elżbieta Janicka, Tomasz Żukowski, Przemoc filosemicka? Nowe polskie narracje o Żydach po roku 2000 (Warsaw, 2016), 17-76.

${ }^{73}$ Ibid., 55. 
their analysis, Janicka and Żukowski highlight the important role of the "good Jew" in a Polish self-esteem process. They claim that the figure of a "good Jew" equips Poles with a "morality certificate, absolving them, denying accusations of antisemitism and at the same time agreeing for the antisemitic behavior, meaning condemning the 'bad Jews,' and finally accepting the history of the majority." 74

Vincenz's Jewish heroes are always the "good Jews" and indeed he pictures them usually placed in the safe zone of their homes, enjoying good relations with their neighbors. Still, it is difficult to think of Vincenz trying to produce a manipulation of the kind described in Janicka's and Żukowski's book. Silence in his work was his answer to the endless pain and disappointment experienced within a world of lost human values. However, it does not seem that Vincenz tried to put a spell on reality and recall only the happy times. All the facts about the problematic coexistence between Poles and Jews in the nineteenth-century Eastern Carpathians or in Lwów between the world wars do exist in his prose, but they exist there silently.

Appelfeld's direct experience of the Holocaust was different from Vincenz's indirect one (in the sense that Vincenz observed the Holocaust from a distance, through the experiences of his close friends). Unlike Vincenz he was Jewish, and was a child during the Holocaust. His way of "working through the trauma" 75 was bound to be much more complex. But similar to Vincenz, one of the important tools he chose to express himself with was silence—a fact also pointed out by Gila Ramras-Rauch:

One would think that Appelfeld, having been torn from both homeland and language, would have little chance of articulating his experiences through fiction. But, furnished with a fund of broken languages, Appelfeld was meant to be a writer. He now knows that silence can signify not only acquiescence but also strength. And if verbal expression reflects order, then silence might entail chaos. For his verbally impaired characters he creates a narrative space in which silence gains significance. Their fragmented relationship to objects and people is often shrouded in silence. ${ }^{76}$

Katarzyna Liszka, analyzing the relation between ethics and memory after the Holocaust, brings up Avishai Margalit's question about whether forgetfulness is something an individual can control. The will to forget does

${ }^{74}$ Ibid., 68.

${ }^{75}$ La Capra's term "working through the trauma" is analyzed in a book by Katarzyna Liszka. See Katarzyna Liszka, "Przepracowanie jako ideał regulatywny," in ead., Etyka i pamięć o Zagładzie (Warsaw, 2016), 17-24.

${ }^{76}$ Ramras-Rauch, Aharon Appelfeld, 17. 
not provide an immediate possibility of deleting parts of the painful or unwanted past from memory. ${ }^{77}$ Both authors seem to control their oblivion. However, one must not forget that while Appelfeld was a Holocaust survivor, Vincenz had very little exposure to wartime events, and lived in exile throughout the war. As a result, the attempt to draw commonality between both authors' adoption of silence as a literary tool may be considered as insensitive to the authors' reflective personal experience. One could argue that Vincenz deliberately erases inter-ethnic violence while Appelfeld's silence is post-traumatic. Therefore, the conclusion regarding both authors' control over their oblivion should be further developed. Nonetheless, their silence carries deep meaning. Reading Vincenz and Appelfeld as historiographic metafiction is to read their silence.

\section{Bibliography}

\section{Archival documents}

Biblioteka Zakładu Narodowego im. Ossolińskich we Wrocławiu, collection: Archiwum Stanisława Vincenza, call no. 17550.

\section{Primary sources}

Appelfeld, Aharon, All Whom I Have Loved, trans. Aloma Halter (New York, 2007). Appelfeld, Aharon, The Story of a Life, trans. Aloma Halter (New York, 2004). Appelfeld, Aharon, Tzili: The Story of a Life, trans. Dalya Bilu (New York, 1983). Najder, Marceli, Rewanż (Warsaw, 2013).

Vincenz, Stanisław, Na wysokiej połoninie: Barwinkowy wianek. Epilog (Warsaw, 1983).

Vincenz, Stanisław, Na wysokiej połoninie: Prawda starowieku. Obrazy, dumy i gawędy $z$ Wierchowiny Huculskiej (Warsaw, 1980).

Vincenz, Stanisław, On the High Uplands: Sagas, Songs, Tales and Legends of the Carpathians, trans. Henry Charles Stevens (London, 1955).

Vincenz, Stanisław, Outopos: Zapiski z lat 1938-1944 (Wrocław, 1992).

Vincenz, Stanisław, Po stronie dialogu (Warsaw, 1983).

Vincenz, Stanisław, Tematy żydowskie (Gdańsk, 1993).

Vincenzowa, Irena,“Rozmowy ze Stanisławem Vincenzem 6 IX 1953,” Regiony (1993), no. 2.

Vincenzowa, Irena, "Rozmowy ze Stanisławem Vincenzem 22 III 1954," Regiony (1993), no. 2.

Vincenzowa, Irena, “Rozmowy ze Stanisławem Vincenzem 8 I 1960,” Regiony (1995), no. 2.

${ }^{77}$ Liszka, Etyka i pamięć o Zagładzie, 26. 


\section{Secondary sources}

Bilsky, Leora, "Judging Evil in the Trial of Kastner," Law and History Review 19 (2001).

Burda-Fischer, Dorota, Stanisława Vincenza tematy żydowskie (Wrocław, 2015).

Epstein, Leslie, “'Child of His Time,' Holocaust survivor Aharon Appelfeld, Israel's greatest living writer and author of the new 'Until the Dawn's Light,' retains his capacity for wonder," an on-line article based on a lecture delivered at the International Conference on the Life and Work of Aharon Appelfeld, held at the University of Pennsylvania on 26 and 27 October 2011. http://www. tabletmag.com/jewish-arts-and-culture/books/83325/child-of-his-time [retrieved: 8 June 2019].

Grynberg, Henryk, "Forma pamięci," Kultura (1978), no. 6.

Ibsch, Elrud (ed.), The Conscience of Humankind, Literature and Traumatic Experiences (Amsterdam-Atlanta, 2000).

Janicka, Elżbieta, Żukowski, Tomasz, Przemoc filosemicka? Nowe polskie narracje o Żydach po roku 2000 (Warsaw, 2016).

Kaczmarek, Michał, Proza pamięci: Stanisława Vincenza pamięć i narracja (Toruń, 2009).

Kuryluk, Ewa, Kangór z kamera (Kraków, 2009).

Liszka, Katarzyna, Etyka i pamięć o Zagładzie (Warsaw, 2016).

Mishani, Dror, "Bein Rechavia le-Mea Shearim" [Between Rechavia and Mea Shearim], Ha'aretz (9 Sept. 2006).

Ołdakowska-Kuflowa, Mirosława, Stanisław Vincenz: Biografia (Lublin, 2006).

Onega, Susana, "A Knack for Yearns: The Narrativization of History and the End of History," in ead. (ed.), Telling Histories: Narrativizing History, Historicizing Literature (Amsterdam-Atlanta, 1995).

Prokop-Janiec, Eugenia, "Na wysokiej połoninie: Obrazy, dumy i gawędy z Wierchowiny Huculskiej: Motywy żydowskie wobec literatury Dwudziestolecia," in Mirosława Ołdakowska-Kuflowa (ed.), Stanisław Vincenz - humanista XX wieku (Lublin, 2002).

Ramras-Rauch, Gila, Aharon Appelfeld: The Holocaust and Beyond (Bloomington-Indianapolis, 1994).

Rattok, Lily, Bait al blima: omanut ha-sipur shel A. Appelfeld [A Precious House: The Narrative Art of A. Appelfeld] (Tel Aviv, 1989).

Sagi, Avi, Lipsker, Avidov (eds.), 24 kri'ot be-kitvei Aharon Appelfeld [Twenty-four Readings in Aharon Appelfeld's Literary Work] (Tel Aviv, 2011).

Schwartz, Yigal, Omanut ha-sipur shel Aharon Appelfeld [The Narrative Art of Aharon Appelfeld] (Or Yehuda, 2014).

Dorota Burda-Fischer

University of Haifa

dburda-fi@univ.haifa.ac.il 